\title{
Nowa deiksa? Nowa anafora? Nowa semantyka? Językowa gra w oczywistość płci
}

New deixis? New anaphora? New semantics? Language game

and the obviousness of sex marking

\section{Arkadiusz Jabłoński}

Uniwersytet im. Adama Mickiewicza w Poznaniu yaboo@amu.edu.pl | ORCID: 0000-0002-0812-4142

\begin{abstract}
The investigation of language and language processes is based on the assumption that they are related to a certain verifiable reality. Still, not all parameters of language express the reality in an exact manner. Moreover, the postulate to render strictly the actual properties of designates in language may reveal the hallmarks of a manipulative communication game. In the paper, an analysis of some fragmentary, chosen, although in the general perspective viewed as representative examples of use of certain elements of deictic and anaphoric character in marking the sex of a designate (not always identical with the grammatical value of gender in Polish) is proposed in terms of such a game in the texts from the contemporary Polish communicative domain.
\end{abstract}

Keywords: "feminatives", careless relations, anaphora, grammatical gender 



\section{Gry w pragmatyce językoznawczej}

W badaniu przekazu w modelu gry, całości komunikacyjnej o ustalonych regułach i przewidywalnym zakresie wartości wyniku, można odwołać się do takich cech, jak ludyczność (Huizinga, 1985; Caillois, 1985), semiotyczność (Guiraud, 1974), teatralność (Goffman, 2000) i psychologiczne tło zachowań (Berne, 1999). Odnoszą się one w sposób rozmaity do „rzeczywistości dnia codziennego" (Berger, Luckman, 1983).

Aktywność komunikacyjna nie uwzględnia wyłącznie faktów. W kontekstach zaawansowanych cywilizacyjnie występują relacje mniej ściśle związane z rzeczywistością. Zarazem nie wszystkie aspekty użycia języka w terminach gier przejawiają cechy wyłącznie w sposób niewinny ludyczne lub kreatywne.

Model gier wykorzystywano w badaniu relacji osadzonych w realiach międzykulturowych (Jabłoński, 2018, 2019), z wyróżnieniem nieuprawnionego użycia wątków fikcyjnych w tendencyjnym opisie zjawisk innej kultury. Podobny aparat wydaje się odpowiedni do analiz rytuałów komunikacyjnych kultury rozumianej jako twór homogeniczny, w ramach której rzeczywistość (przedmiot poznania) jest nader często widziana jako poznawalny monolit, co do którego badacz (podmiot poznania) dysponuje bezdyskusyjną, całościową wiedzą. Akt taki może posłużyć weryfikacji, czy pewne nowe w polszczyźnie zjawiska dotyczące znaczenia płci desygnatu rzeczywiście rozwiązują problemy komunikacyjne. Ponadto, niezależnie od niepodlegającego dyskusji faktu rozpowszechnienia zjawiska (wolno w jego przypadku mówić o zwrotnym upłciowieniu terminów, które - co niewykluczone - w polszczyźnie historycznie zrazu wykazywały bezpośrednie powiązanie z płcią, charakter ten wszakże w procesie rozwoju języka zatraciły), nie sposób dowieść jednoznacznie, że problemy, jakie taki proces językowy ma podobno rozwiązywać, istnieją w rzeczywistości. Właśnie ustalenie tych kwestii - raczej niż normatywną ocenę pewnych trendów językowych - postanowiono przyjąć jako cel badawczy artykułu.

\section{Model gry rodzinnej}

Wybrany model opisowy gry, wykorzystany po raz pierwszy przez Erica Berne’a, czytelnie wyznacza opozycję terminów „gra” i „rzeczywistość”. 
Adaptowany model wyróżnia ponadto odrębne cele komunikacji, definiowane w ramach schematu psychologicznej triady rodzinnej.

DZIECKO: „intuicja, twórczość, spontaniczna energia, radość”,
DOROSŁY: „niezbędny do przetrwania, [...] przetwarza dane”,
RODZIC: „wykonuje wiele reakcji automatycznie” (Berne, 2000, s. 16-20).

DZIECKO przetwarza dane z kreatywnym odniesieniem do faktów. DOROSŁY uwzględnia dane weryfikowalne. RODZIC wdraża odgórną, nieweryfikowalną tezę o cechach przekonania arbitralnego celem skrócenia ścieżki decyzyjnej.

W różnych sytuacjach przydatność przejawia inny składnik modelu. W perspektywie pragmatycznej osiągane są cele łączące się w różny sposób z rzeczywistością (identyfikacja i rozwikływanie istniejących problemów) lub osadzone w nie-rzeczywistości gry (w tym implikujące manipulację i ideologizację czynników jedynie pośrednio powiązanych z rzeczywistością). Brak dopasowania ról uczestników komunikacji w ramach triady rodzinnej prowadzi do transakcji skrzyżowanych, bezproduktywnych, nieefektywnych komunikacyjnie.

\section{Bezproduktywność: po co?}

Bezproduktywność (gier) jest dopuszczalna w kontekście produktywności pragmatycznej („nie-gier”). Modelowa triada pozwala wyróżnić trzy techniki komunikacji (Jabłoński, 2016).

Relacje fachowe rozróżniają fakty i fałsz w racjonalnym przetwarzaniu faktów. Dotyczą one „nie-gry”. Sytuująsię wdomenieDOROSŁEGO. Dominują w źródłach eksperckich.

Relacje niefachowe to wytwory nadmiarowe, spotykane w cywilizacjach rozwiniętych, odnoszące się do "gry” w przedstawieniu subiektywnej interpretacji faktów, w najlepszym razie częściowo weryfikowalnych. Należą one do domeny DZIECKA i dotyczą pewnej konwencji orzekania, zwykle jasnej dla odbiorcy, który ją odczytuje i przyjmuje - jak w przypadku utworów literackich i realizacji poetyckiej funkcji języka.

Relacje niedbałe to swoisty gatunek "gry w antyinformację" $\mathrm{z}$ domeny RODZICA. Naśladują one narracje FACHOWE, jednak z narzuceniem 
odgórnej tezy w interpretacji faktów. Powoduje to polaryzację lub hiperbolizację faktów (mniej istotnych), jako zgodnych lub niezgodnych z (bardziej istotną) tezą nadawcy, która często jest dyktowana jego światopoglądem i zdominowana odniesieniami normatywnymi. Celowe przemieszanie wątków niedbałych $\mathrm{z}$ elementami relacji fachowych i niefachowych to nadużycie komunikacyjne.

Dalej zestawiono trzy wybrane zjawiska dotyczące odniesienia do płci, które omówiono na przykładach współczesnych użyć polszczyzny: kwestie rodzaju gramatycznego, deiksy (ściślej: anafory i katafory) oraz eksponowania parametru płci w dyskursie o raczej nikłym odniesieniu merytorycznym. Rzeczywiste ich powiązania mogą podlegać dyskusji. Za charakterystyczne wypada uznać rozpowszechnianie się binarnego, sztywnego odniesienia do wartości płci, w tym w kontekstach, w których dotąd parametru tego nie akcentowano.

\section{0 języku i płci: fachowa perspektywa DOROSŁEGO}

Elementy analizowane pogrubiono. W zdaniach przykładowych bez oznaczenia źródła gwiazdka (*) sygnalizuje uzus dyskusyjny. Wykrzyknik (!) uzus nacechowany lub niekonwencjonalny. Symbol [o] znaczy opuszczenie elementu.

\subsection{Rodzaj gramatyczny}

Polskie rzeczowniki wykazują wartości wymiaru rodzaju gramatycznego w trójelementowym paradygmacie: męski, żeński, nijaki. Wartość ta warunkuje, w sposób nie zawsze jednoznaczny, dobór wzorca deklinacyjnego i determinuje formę określającego przymiotnika oraz orzeczenia zdania. Nie jest jednak sztywno powiązana z płcią metrykalną desygnatu:

kobieta «dorosły człowiek płci żeńskiej» (Dubisz, 2003, t. 2, s. 141)

mężczyzna «osoba dorosła płci męskiej» (Dubisz, 2003, t. 2, s. 622)

człowiek 1. «Homo sapiens, istota żywa wyróżniająca się najwyższym stopniem rozwoju psychiki i życia społecznego, jedyna posiadająca kulturę i zdolna do jej tworzenia» [...] (Dubisz, 2003, t. 1, s. 523-524)

osoba 1. «jednostka ludzka; człowiek; postać» (Dubisz, 2003, t. 2, s. 1316) 
W jednostkach kobieta i mężczyzna wartość rodzaju jest tożsama z płcią. Druga z jednostek, mimo gramatycznego rodzaju męskiego, wykazuje żeński wzorzec deklinacji. Rzeczowniki takie jak człowiek czy osoba niezależnie od ich rodzaju gramatycznego nie odnoszą się ponadto wyłącznie do desygnatów żeńskich lub męskich.

\subsection{Od rzeczowników kategorialnych do deiksy}

Nazwy zawodów i stanowisk, w przeważającej części rodzaju męskiego, nie wykazują bezpośredniego powiązania z płcią. Ich desygnat nie musi być metrykalnym mężczyzną.

polityk 1. «osoba biorąca czynny udział w życiu politycznym państwa, często kierująca polityką państwa» (Dubisz, 2003, t. 3, s. 319)

rektor 1. urz. «przełożony szkoły wyższej [...]» [...] 2. rel. a) «przełożony seminarium duchownego [...]»b) «ksiądz rezydujący przy kościele nieparafialnym» 3. histor. «w dawnej Polsce: przewodniczący szkół przykościelnych i zakonnych, a także szkół elementarnych» (Dubisz, 2003, t. 3, s. 920)

socjolog socjol. «specjalista w dziedzinie socjologii» (Dubisz, 2003, t. 3, s. 1293)

Potencjalne nacechowanie płciowe narzucają nie cechy języka, ale wymogi zewnętrzne, jak w punktach 2, 3 i 4 definicji jednostki rektor. Język bezpośrednio nie uzasadnia ich ani ich nie wspiera. Wartość płci desygnatu przejawia się najsilniej w terminach pokrewieństwa, imionach i nazwiskach, znosząc często konieczność jej zaznaczania w określeniach kategorialnych.

Dane i fakty fachowe nie dopuszczają negatywnej odpowiedzi na pytanie: „Czy kobieta może być politykiem, rektorem, socjologiem?”. Rzeczowniki o rodzaju gramatycznym niepowiązanym sztywno z płcią są neutralne wobec opozycji płciowej sensu stricto: kobieta - mężczyzna. Alternatywnie wobec cech obiektu konkretnego płciowo, osobowego, wyrażają one odniesienie do niekonkretnego statusu lub stanowiska (por. nowa rektor, młoda polityk, polska socjolog). Użycie takie, podobnie jak użycie kategorialne (nie: konkretne) jednostek człowiek i osoba, wykazuje możliwie nikłe nacechowanie dyskryminacją płci. Nieregularności w tym aspekcie języka można uznać za incydentalne i niemiarodajne systemowo.

Pewne terminy mają symetryczne odpowiedniki płciowe, jak w parze aktor: aktorka. Wykazują one opozycję w użyciu konkretnym. Zarazem 
ich zastosowanie kategorialne zwykle neutralizuje wartość płci. Można w uzasadnionym uproszczeniu uznać, że najczęściej następuje to zgodnie z domyślnym odniesieniem raczej do właściwości i kompetencji niezależnych od płci (poniekąd zgodnie z akceptacją raczej niekwestionowanego współcześnie braku wpływu wartości parametru płci na kompetencje i tożsamość w zakresie odniesienia tych terminów):

a) Zawód: aktor.

b) Kwalifikacje aktora.

c) Związek zawodowy aktorów.

d) Teatr jednego aktora.

e) Znaczacy aktor na scenie europejskiej polityki.

W użyciu kategorialnym (a-d), przechodzącym płynnie w metaforyczne (d-e), zachodzi jednostronna neutralizacja płci. Aktorką nie może być desygnat męski.

W zdaniach b, c i d można dopuścić użycie odpowiednika żeńskiego aktorka. Konkretne odniesienie do płci, o ile wnosi coś nowego do warstwy referencyjnej przekazu, odwraca jednak uwagę od innych parametrów w sposób nie zawsze pożądany, także potencjalnie dyskryminacyjny (c).

Za wątpliwe uznać trzeba przypadki mylenia kryteriów konkretnych i kategorialnych (f-i):

f) kandydat na rektora

g) kandydatka na rektora

h) *kandydatka na rektorkę

i) *kandydat na rektorke

Alternatywnie wobec neutralnego przykładu f przykład g dotyczy konkretnej kandydatki, o ile wskazane jest zaznaczenie płci. Wersje $h$ oraz i są zbędnie nacechowane wartością płci.

Podobnie kształtują się reguły doboru innych elementów zdań:

j) Rektorzy szkót wyższych spotkali się.

k) *Rektorzy i rektorki spotkali się.

1) *Rektorzy spotkali się i rektorki spotkały się.

Nadmiarowe jest użycie, zamiast wypowiedzi j, jej nacechowanych płciowo wersji k lub l. Poza raczej iluzoryczną ideą spotkań delegatów odrębnych płci (l) tożsamość konkretnych pojedynczych desygnatów jest albo pewna, albo nieistotna w grupowym wzmiankowaniu mnogim. 
Trudno orzec tu upośledzenie desygnatów żeńskich. Także w dwubiegunowym płciowo modelu rzeczywistości ani postaci męskoosobowe, ani niemęskoosobowe nie dotyczą wyłącznie obiektów męskich lub żeńskich.

Zaimki osobowe w liczbie pojedynczej: on, ona, jednoznacznie i konkretnie znaczą płeć desygnatu. W liczbie mnogiej używane są, siłą rzeczy nieprecyzyjne, postaci męskoosobowe i niemęskoosobowe (m) Użycie odrębne służy podkreśleniu treści nietypowych (n), także w celowo kontrastowym ujęciu płci (o):

m) Rozmawiałem z Kowalskimi. Oni myśla, że to zły pomysł.

n) Rozmawiałem z Kowalskimi. I ona, i on myśla, że to zły pomyst.

o) !Oni szli na front, a one toczyły walkę o przetrwanie rodzin.

\subsection{Anafora i katafora}

Anafora to technika przywołania elementu znanego. Wobec zgodności wartości podmiotu i orzeczenia pod względem osoby i liczby, a nierzadko takżei rodzaju, następuje wielokrotnie poprzez opuszczenie (wyzerowanie) elementu (p). Jedynie podkreślenie odniesienia do desygnatu uprawnia użycie zaimka osobowego (pronominalizację [q]):

p) Krystyna jest Polka. [o] Mieszka w Kutnie.

q) !Krystyna jest Polka. Mieszka ona $w$ Kutnie.

We współczesnej polszczyźnie często anaforycznie pojawia się hiperonimizacja (użycie elementu o szerszym znaczeniu: $r-s$ ):

r) *Krystyna jest Polka. Kobieta mieszka w Kutnie.

s) *Krystyna jest Polka. 23-latka mieszka w Kutnie.

Zabieg taki, zwykle niewymagający znacznego wysiłku interpretacyjnego wobec oczywistego i jednoznacznego odniesienia do płci lub wieku innymi środkami, można wywodzić z wpływu angielszczyzny, w której brak zgodności wartości podmiotu i orzeczenia wymusza niejako takie rozwiązanie, w języku polskim przeważnie zbędne - poza sytuacjami ewidentnego dysonansu poznawczego, gdy wymóg podania informacji koliduje z brakiem przesłanek do innej niż płciowa identyfikacji desygnatu, np. w trakcie autopsji denata o nieznanej tożsamości. Hiperonimizacja budzi niekiedy skojarzenia z twórczością wymuszoną w użyciach o różnym stopniu udolności formulacyjnej $(\mathrm{t}-\mathrm{u})$. Można użyć tej techniki 
w tekstach specjalistycznych (v) Niedopuszczalne jest anaforyczne użycie w przykładzie v elementu mężczyzna, mimo zgodności z płcią desygnatu.

t) !Studenci rozpoczęli sesję. Żacy zajęci są nauką.

u) !Znaleziono rower. Jednoślad był kradziony.

v) Polityczne wybory Miłosza. Czy polski noblista był postacia kontrowersyjna??

Katafora to odwołanie do elementu nieznanego, wprowadzanego później (w). Technika taka zanika w użyciu niewyszukanym, na rzecz nieuprawnionej hiperonimizacji. Podobnie jak anafora, dotyczy ona zwykle nadmiarowej wzmianki o płci i wieku (x):

w) [o] Miał 5 promili alkoholu we krwi i prowadzit samochód. Kierowce zatrzymała policja.

x) *Mężczyzna miał 5 promili alkoholu we krwi i prowadził samochód. 45-latka zatrzymała policja.

Uproszczeniem byłoby potraktowanie anaforycznego lub kataforycznego znaczenia płci jako powiązanego $\mathrm{z}$ wymuszeniem parametru płci. Współwystąpienie tych zjawisk ma jednak często skutki karykaturalne.

\section{0 języku i płci: niefachowa perspektywa DZIECKA}

\subsection{Kreatywność doraźna}

Płeć można znaczyć w sposób kreatywny i niestandardowy. Dzieje się tak w użyciu zarządzanym przez spontaniczną aktywność elementu DZIECKO w modelu relacji celowo niefachowej:

y) !To moja psa/piesa. [żartobliwie o ulubionej suce]

z) !Nasza dzisiejsza gościni to... [kreatywność niewymuszona]

aa) !Uważaj na facetkę. [kreatywność slangowa]

ab) !Byt na dywaniku u dyrektorki. [kreatywność potoczna]

ac) !Piwnica Prezydentki Internetu [ironiczna nazwa grupy w serwisie społecznościowym]

ad) *Pierwsza wiceprezydentka Ameryki. [sztuczne narzucenie obligacji znaczenia płci] 


\subsection{Użycie metaforyczne $i$ kategorialne}

Kreatywność nie równa się obligacji zaznaczania parametrów oczywistych. Ta ostatnia przesuwa punkt ciężkości z braku związku między płcią a formą gramatyczną (ae) na (często karykaturalny) wymóg językowego akcentowania płci (ad, af) O ile formy obiekta nie zdołano dotąd zarejestrować, bezrefleksyjna forma gościni (z) lub podobne (ad) występują już stale w idiolekcie pewnych osób publicznych. Tłumaczyć to można jedynie błędnym założeniem z góry, wbrew faktom językowym, męskiego i potencjalnie dyskryminacyjnego odniesienia neutralnej płciowo jednostki gość.

ae) Polityk stała się obiektem nasilonej krytyki ze strony ekspertów.

af) *Polityczka stała się obiektą nasilonej krytyki ze strony ekspertek.

\section{0 języku i płci: NIEDBAŁA perspektywa RODZICA}

\subsection{Hiperonimizacja}

Przykłady hiperonimizacji płci lub wieku występują nawet w tytułach tekstów, jak w ag-ah:

ag) „Śmiertelny wypadek przy remoncie bloku. Mężczyzna spadł $\mathrm{z}$ rusztowania (ePoznań.pl, 202ob).

ah) „Oszuści wyłudzają kody BLIK na Messengerze. 29-latek stracił 2 tys. zł" (ePoznań.pl, 2020a)

Użycie takie nie wyklucza znajomości innych technik anaforycznych, jak w ai i aj:

ai) „Mężczyzna wezwał wszystkie służby, bo [o] chciał sprawdzić, jak szybko przyjadą [...] do [...] policjantów zadzwonił mężczyzna. [...] u mieszkańca gminy Lipka odbywało się spotkanie [...], [...] mężczyzna spożywał [...] alkohol. Kiedy zgłaszający był już w znacznym stanie upojenia, [o] postanowił dla »żartu « powiadomić [...] służby [...]" (ePoznań.pl, 2020c).

aj) „Ten związek wzbudzał silne emocje [...]. Kamila Łapicka poznała swojego przyszłego męża w redakcji miesięcznika »Teatr«. Andrzej Łapicki, starszy od niej o 60 lat, od razu się nią zainteresował. I choć wszyscy ostrzegali aktora, że kobiecie zależy tylko na jego pieniądzach 
i prestiżu, para szybko wzięła ślub. [...] Trzy lata później, w 2012 roku, Andrzej Łapicki zmarł. [o] Miał 88 lat" (Niewiadomska, 2020).

Jednocześnie zaciera się granica efektywnego użycia omawianych technik. Być może w odczuciu autora tekstu aj dopuszczalne byłoby wzmiankowanie wieku lub płci nawet w ostatnich dwóch zdaniach.

\subsection{Symetria rodzaju i ptci?}

Przekonanie (raczej naiwne) o symetrii związku płci z formą znaczników statusu, specjalności i zawodu obrazują przykłady ak i al.:

ak) „Analizuje funkcjonowanie polityki w sieci. Specjalistka marketingu sektora publicznego [...]. Kilka lat temu była dyrektorką biura [...]. Dla OKO.press pisze jako autorka zewnętrzna" [profil autorski] (Mierzyńska, 2020).

al) „[... Swoje oburzenie wyraziła między innymi polityczka Hanan Al-Fatlawi, która nazwała oświadczenie banku »haniebnym «" (JoeMonster.org, 2020).

\subsection{Wymuszona binarność}

Wymuszona binarność znaczenia płci występuje coraz częściej. A przecież zapewne nawet redakcja czasopisma o poglądach niewywrotowych (am i an) nie uznaje raczej, że przed językową binarną rewolucją było ono redagowane wyłącznie dla czytelników płci męskiej:

am) „Artykuł czasowo dostępny bezpłatnie w prezencie dla Czytelniczek i Czytelników" [wiadomość serwisowa] (Radzik, 2020).

an) „Bycie za życiem to też walka z ubóstwem i budowanie równości [...]. To przyjmowanie uchodźców i tworzenie przyjaznej przestrzeni dla migrantek [...]" (tamże).

Na marginesie można wspomnieć, że istnieją także - w tej analizie pominięte - przypadki ewidentnych nadużyć w postaci eksponowanego stosowania wyłącznie form żeńskich, nacechowanych i ekskluzywnych, wykluczających otwarcie płeć męską desygnatu, w miejsce nienacechowanych, inkluzywnych form męskich. Chwiejność powiązań rodzaju i płci obrazuje błędne odniesienie $\mathrm{w}$ an do migrantek (wyraźnie przecież nie chodzi jedynie o desygnaty żeńskie). Walkę z neutralnym płciowo językiem w imię rzekomo binarnej równości odzwierciedla przykład ao ze źródła otwarcie wywrotowego. Nietrudno rozpoznać w tle tego użycia 
odgórną tezę RODZICA, że jedynie binarnie płciowa językowo rzeczywistość jest słuszna.

ao) „Widziałyście i widzieliście Morawieckiego? Tego tchórza bredzącego o tym, żeby protestować, ale jednak nie za bardzo?" (Ogólnopolski Strajk Kobiet, 2020).

Nadużycia takie wykazują wyraźną, choć niezmiennie raczej luźno powiązaną z faktami językowymi, insynuację rzekomej dyskryminacyjności dotychczasowego nacechowania płciowego form męskoosobowych.

\subsection{Rektorki}

Teksty ap-ar opublikowano w roku wyborów uczelnianych, w kolejnych etapach kampanii wyborczej:

ap) „Socjolożka: w Polsce rektorami są zwykle panowie po 50. Brakuje rektorek" (Tomala, 2020).

aq) „Na uniwersytetach rektorami są sami mężczyźni. UAM może to zmienić. [...] Bogumiła Kaniewska, kandydatka na rektorkę Uniwersytetu Adama Mickiewicza w Poznaniu" (Nyczka, 2020).

ar) „Czas rektorek. Kobiety coraz częściej rządzą uczelniami. [...] Rektorzy i rektorki obecnej kadencji będą w większym stopniu rozliczani” (Sajór, 2021).

Stwierdzenie "braku rektorek” z ust *socjolożki (ap) może stanowić odzwierciedlenie przekonania o konieczności wdrożenia w tej dziedzinie parytetu płci. Hipoteza ta i samo założenie „braku” podlegają jednak zwykle w ujęciu fachowym pewnym procedurom intersubiektywnej weryfikacji. Tu uznano z góry ich słuszność, w sposób typowy dla RODZICA. Analiza fachowa faktów z domeny DOROSŁEGO wykazuje, że w uczelni macierzystej autora niniejszego artykułu problem rozwiązano przez zgłoszenie konkretnej kandydatki w wyborach na rektora. Nieznane są okoliczności, jakie dotąd uniemożliwiały taki krok. Teksty cytowane wyżej nasuwają za to forsowaną usilnie w retoryce RODZICA konkluzję, że płeć rektora stanowi parametr pierwszorzędny. Z tekstu ar można by nawet wnioskować, że zmiany przebiegają wyłącznie według parametru płci. Ponownie w charakterystyczny sposób odgórne, subiektywne przekonania autorów tekstów zdają się w nich zastępować konfrontację z faktami pozajęzykowymi i pozapłciowymi. 


\subsection{Nowa semantyka?}

Na marginesie wskazanych zjawisk zwraca uwagę akcentowanie priorytetu płci w tematyce niezwiązanej w sposób jednoznaczny lub wcale z płcią:

as) „Kraje, które najlepiej sobie radzą z kryzysem pandemicznym, są rządzone przez kobiety. Od Nowej Zelandii, przez Niemcy, Tajwan czy Finlandię i Islandię, od Jacindy Ardern po Angelę Merkel. Przywódczynie umiały sprawnie i skutecznie ustawiać priorytety, definiować główne cele i je realizować" (Holland, 2020).

at) „Obama przyznał, że kobiety nie są doskonałe, ale są «bezdyskusyjnie lepsze» od mężczyzn.

$[\ldots]$

- Jestem całkowicie przekonany, że w ciągu dwóch lat, gdyby każdym państwem na świecie rządziły kobiety, wówczas doszłoby do znaczącej poprawy na każdym polu - stwierdził Obama" (Rp.pl, 2019).

au) „Myślę, że to głupie ze strony kobiet, by udowadniać, że są równe mężczyznom. One są znacznie lepsze i zawsze były. Cokolwiek dasz kobiecie, ona czyni to lepszym. Jeśli dasz jej spermę, da Ci dziecko. Dasz jej zakupy, ona da Ci posiłek. Dasz jej uśmiech, ona da Ci swoje serce. Mnoży i powiększa wszystko, co się da. Więc jeśli dasz jej gówno, spodziewaj się jeszcze większego gówna. - William Golding" (WielkieSlowa.pl, 2020).

O ile w przykładzie as można, ze względu na osobę autorki, odczytać prowokację artystyczną (co odsuwa na plan dalszy kłopotliwą weryfikację faktów), o tyle at to przykład hojnego szafowania półprawdą przez polityka. Tekst au, cytowany często przez liczne inne źródła, w tym przez wpisy na profilach w mediach społecznościowych, w kontekście jego rzekomej rewolucyjności, o ile jest autentyczny, stanowi egzemplifikację jawnego seksizmu i uprzedmiotowienia kobiet w retoryce prymitywnego paternalizmu („dasz jej spermę, da ci dziecko”). Niedbałe odniesienie do faktów w relacji dominowanej przez RODZICA narzuca skrzywiony obraz spartakiady płci, w której jedynie ten parametr rozstrzyga bezpardonowy bój o iluzoryczny prymat. Prostota przekazu czyni ów obraz nośnym. Obniża jednak zdecydowanie jego jakość poznawczą. Uderza przy tym podobieństwo stylistyki takich pozornie nowatorskich relacji do użycia kategorycznych tez RODZICA - zgoła odmiennej treści - w nacechowanym konserwatywnie przekazie moralnym i sakralnym, wobec którego sam postulat weryfikacji 
tezy głównej uznany byłby za herezję. W tej samej retoryce niniejszy artykuł może być odebrany przez zwolenników (i zwolenniczki) obligatoryjnego znaczenia płci jako skowyt ginącej paternalistycznej reakcji.

\section{Asocjacje pragmatyczne}

Odniesienie pragmatyczne wiąże (językowy) ZNAKi (pozajęzykowy) EFEKT w terminach „pochodzenia, uzusu i efektów wdrożenia znaków w ramach zachowań [językowych]” (Morris, 1946, s. 219). Relacje niedbałe dotyczące płci lekceważą fakt, że „Nie każdy atrybut osobisty liczy się dla ustalenia, czy dwaj ludzie są wystarczająco powiązani relacją solidarności" (Brown, Gilman, 1960). Dzieje się tak w imię przyjęcia roli RODZICA w grze, z naciskiem na to, by „obserwatorzy traktowali poważnie wywierane na nich wrażenie” (Goffman, 1956, S. 10), a w tym przypadku nawet, by „wierzyli, że widziany przez nich bohater rzeczywiście wykazuje atrybuty, jakie wydaje się posiadać” (tamże). „Sytuacyjne właściwości jednostki komunikującej się dotyczą tych cech [...], przez które przystosowuje się ona do zmiennych komunikatywnie relewantnych sytuacji [...]" (Yngve, 1975). Narzucenie obligacji znaczenia płci następuje przy tym w retoryce forsowanego binarnego sporu:

Przekonanie, że zawsze istnieją dwie strony medalu, nieraz prowokuje [...] do zgłębiania tej „drugiej strony” i w rezultacie rozmaici wygadujący niestworzone historie szarlatani uzyskują możliwość wygłaszania swoich wątpliwej jakości przemyśleń na forum publicznym (Tannen, 2003, s. 24).

Uzysk referencyjny takich relacji nie jest konstruktywny ani odkrywczy. Już choćby z tego względu, niezależnie od słusznie wskazywanej potrzeby dążenia do społecznej równowagi płci, warto rozważyć jako krok w tym kierunku możliwość jej neutralizacji, zapewnianej skutecznie przez język polski w jego oglądzie fachowym (4.1-4.3).

\section{Podsumowanie}

Analiza fachowa danych językowych wskazuje, że płeć metrykalna - tym bardziej: płeć w perspektywie binarnej jej wzmiankowania (w praktyce 
nawiązującej właściwie bezpośrednio i współcześnie raczej paradoksalnie, by nie powiedzieć: anachronicznie, do archaicznego, automatycznego odniesienia wartości parametru płci głównie lub wręcz jedynie do kontekstu podtrzymania gatunku i rozrodu) - nie jest jedyną ani główną wartością narzucaną przez język polski jego kompetentnym użytkownikom (niezależnie od płci tychże). Potwierdza to konwencjonalny charakter kodu językowego, rozróżniającego więcej niż dwie wartości rodzaju. Nie do końca binarna płciowo jest także zresztą, co szczególnie wypada podkreślić, rzeczywistość pozajęzykowa.

Język może się zmieniać. Warto jednak znać przyczynę, cel i skutek zmian. Konkluzja owa wykazuje aktualność tym bardziej, że produkty "nowej semantyki” (6.5), nawiązujące do (aż nader) prosto ujmowanej, rzekomo wszechobecnej walki płci, nie odbiegają znacząco od relacji niedbałych wobec kultur heterogenicznych, umacniających szkodliwe stereotypy (Jabłoński, 2013, s. 197-210).

W perspektywie fachowej wszelkie hipotezy na temat związku rzeczywistości i języka formułowane pierwszorzędnie lub wyłącznie przez pryzmat sztywnego odzwierciedlenia binarnej wartości płci lub uciśnienia płci przez język w aktualnym kształcie w najlepszym razie wymagają weryfikacji. O wiele ciekawsze niż udzielenie odpowiedzi na pytanie, czy wskazane zjawiska są normatywnie słuszne, byłoby z pewnością ustalenie, co użytkownicy języka ( $\mathrm{z}$ niezbędnym udziałem także użytkowniczek oraz osób niebinarnych płciowo) zyskują z kształtowanego w ten sposób niejako na nowo zbinaryzowanego paradygmatu sztywnego odzwierciedlania parametru płci w języku i myśleniu. Trudno uzasadnić tezę, że przyczynia się ono do rozwiązania istniejących, rzeczywistych problemów. Założenie odgórnej słuszności lub forsowanie roli płci w oglądzie świata wykazuje w tym stanie rzeczy cechy uzurpacyjnej, agresywnej retoryki RODZICA, ignorującego niedbale i apriorycznie potrzebę produktywnej konfrontacji z rzeczywistością. Zweryfikować można za to w sposób stosunkowo prosty, że językową równość zapewnia użycie form neutralnych płciowo. Wszak faktem jest, że kobieta może być - i bywa - rektorem. I rektor - kobietą. Mężczyzna zaś nie może być i nie bywa nigdy - *rektorka. 


\section{Literatura}

Berger, P. L., Luckmann, T. (1983). Społeczne tworzenie rzeczywistości (tłum. J. Niżnik). Warszawa: Państwowy Instytut Wydawniczy.

Berne, E. (1999). W co grają ludzie. Psychologia stosunków międzyludzkich (tłum. P. Izdebski). Warszawa: Wydawnictwo Naukowe PWN.

Brown, R., Gilman, A. (1960). The Pronouns of Power and Solidarity. W: T. A. Sebeok (red.), Style in Language (s.253-276). Massachusetts: MIT Press.

Dubisz, S. (red.) (2003). Uniwersalny słownik języka polskiego. Warszawa: Wydawnictwo Naukowe PWN (t. 1-4).

ePoznań.pl (22 października 2020). Oszuści wyłudzają kody na Messengerze. 29-latek stracił 2 tys. zł. Online: <https://epoznan.pl/news-news-111127-oszusci_wyludzaja_kody_blik_na_messengerze_29_ latek_stracil_2_tys_zl>. Data dostępu: 22 października 2020. ePoznań.pl (23 października 2020). Śmiertelny wypadek przy remoncie bloku. Mężczyzna spadł z rusztowania. Online: <https://epoznan.pl/ news-news-111188-smiertelny_wypadek_przy_remoncie_bloku_mezczyzna_spadl_z_rusztowania>. Data dostępu: 23 października 2020. ePoznań.pl (24 października 2020). Mężczyzna wezwał wszystkie służby, bo chciał sprawdzić, jak szybko przyjadą. Online: <https://epoznan.pl/ news-news-111197-mezczyzna_wezwal_wszystkie_sluzby_bo_chcial_ sprawdzic_jak_szybko_przyjada>. Data dostępu: 24 października 2020. Goffman, E. (1956). The Presentation Self in Everyday Life. Edinburgh: University of Edinburgh, Social Sciences Research Centre.

Holland, A. (2020). Zapiski znad krawędzi. Polityka, 65(42), 26.

Jabłoński, A. (2013). Homeostaza tekstu. Tłumaczenie i komunikacja międzykulturowa $w$ perspektywie polsko-japońskiej. Poznań: Wydawnictwo Naukowe Uniwersytetu im. Adama Mickiewicza.

Jabłoński, A. (2016). Japońskie alter ego. Jeszcze o antyinformacji w narracjachniedbałych. HomoLudens, 8(1),53-63. Online:<https://www.ptbg.org. $\mathrm{pl} /$ wp-content/uploads/2020/05/Arkadiusz-JAB\%C5\%810\%C5\%83SKI-Japo\%C5\%84skie-alter-ego.-Jeszcze-o-antyinformacji-w-_narracjach-niedba\%C5\%82ych_.pdf $>$. Data dostępu: 16 listopada 2021.

Jabłoński, A. (2018). Relacje orientalistyczne o Japonii a gra w antyinformację - studium przypadku. Homo Ludens, 10(1), 69-80. Online: 
$<$ http://new.ptbg.org.pl/wp-content/uploads/2019/11/Arkadiusz-JAB\%C5\%81O\%C5\%83SKI-Relacje-orientalistyczne-o-Japonii-a-gra-w-antyinformacj\%C4\%99-studium-przypadku-1.pdf>. Data dostępu: 16 listopada 2021.

Jabłoński, A. (2019). Ksenofobiczna gra w Japonię - przykład ekstremalny międzykulturowej narracji niedbałej. Homo Ludens, 11(1), 93-106. Online: <https://www.ptbg.org.pl/wp-content/uploads/2020/02/ HL_12_2019_art_5.pdf>. Data dostępu: 16 listopada 2021.

Jabłoński, A. (2020). Is orientalism bad? Between the communication game and the non-game. Homo Ludens, 12(1), 55-71. Online: <https:// www.ptbg.org.pl/wp-content/uploads/2021/01/HL_131_202O_art_03_ Jablonski.pdf $>$. Data dostępu: 16 listopada 2021.

JoeMonster.org (3 listopada 2020). Najdziksze newsy tygodnia. Mocne słowa Kai Godek do prezydenta Dudy. Online: <https://joemonster.org/ art/52051/Najdziksze_newsy_tygodnia_Mocne_slowa_Kai_Godek_do_ prezydenta_Dudy>. Data dostępu: 3 listopada 2011.

Mierzyńska, A. (25 października 2020). ALTERNATYWNI. Kiedy teorie spiskowe niszczą prawdziwe życie. Online: <https://oko.press/ alternatywni-kiedy-teorie-spiskowe-niszcza-prawdziwe-zycie/?utm_ medium $=$ cpc\&utm_source=Facebook\&utm_campaign=teorie_spisko we\&fbclid=IwARoQQTESod3daKzNWmoGmguZRL9gIYL8KnWpGu QDxMCCrnk6KnEpDzOgFdw\#Echobox=1603622672>. Data dostępu: 25 października 2020.

Morris, Ch. W. (1946). Signs, Language and Behavior. New York: George Braziller.

Niewiadomska, K. (3 listopada 2020). Była młodsza od męża o 60 lat. Po jego śmierci zniknęła. Online: <https://kobieta.wp.pl/byla-mlodszaod-meza-o-6o-lat-po-jego-smierci-zniknela-6571590576601792a>. Data dostępu: 3 listopada 2020.

Nyczka, T. (21 maja 2020). Na uniwersytetach rektorami są sami mężczyźni. UAM może to zmienić. Online: <https://www.google.com/url ?sa $=$ t\&rct $=$ j\&q $=\&$ esrc $=$ s\&source $=$ web $\& c d=\& c a d=r j a \& u a c t=8 \& v e d=2 a$ hUKEwjkqea6ouvsAhUJLewKHeWPArYQFjAEegQIBRAC\&url=https\% 3A\%2F\%2Fpoznan.wyborcza.pl\%2Fpoznan\%2F7\%2C36001\%2C2596423 9\%2Ctego-jeszcze.html\&usg=AOvVaw2ADJsYWDGWRaV50FF2tW8n>. Data dostępu: 21 maja 2020. 
Ogólnopolski Strajk Kobiet (5 listopada 2020). Online: <https://www. facebook.com/ogolnopolskistrajkkobiet/photos/widzia\%C5\%82y $\% \mathrm{C}_{5} \% 9 \mathrm{Bcie}-\mathrm{i}$-widzieli\%C $5 \% 9$ Bcie-morawieckiego-tego-tch\% $\mathrm{C}_{3}$ \%B3rza-bredz\%C4\%85cego-o-tym-\%C5\%BCeby-pro/5335253973167224>. Data dostępu: 5 listopada 2020.

Radzik, Z. (2 listopada 2020). To nie do zniesienia. Posłuchajcie, jak bardzo. Online: <https://www.tygodnikpowszechny.pl/to-nie-do-zniesienia-posluchajcie-jak-bardzo-165493>. Data dostępu: 16 listopada 2021.

Rp.pl (16 grudnia 2019). Obama - kobiety są bezdyskusyjnie lepsze od mężczyzn. Online: <https://www.rp.pl/Polityka/191219519-Obama-Kobiety-sa-bezdyskusyjnie-lepsze-od-mezczyzn.html>. Data dostępu: 16 grudnia 2019.

Sajór, G. (4 maja 2021). Czas rektorek. Kobiety coraz częściej rządza uczelniami. Online: <https://www.forbes.pl/kariera/czas-rektorek-na-polskich-uczelniach-az-22-dwie-kobiety-pelnia-funkcje-rektorskie/ yqpe45b>. Data dostępu: 16 listopada 2021.

Tannen, D. (2003). Cywilizacja kłótni (tłum. P. Budkiewicz). Poznań: Zysk i S-ka.

Tomala, L. (14 stycznia 2020). Socjolożka: w Polsce rektorami są zwykle panowie po 50. Brakuje rektorek. Online: <https://naukawpolsce.pap. pl/aktualnosci/news\%2C80235\%2Csocjolozka-w-polsce-rektorami-sa-zwykle-panowie-po-5o-brakuje-rektorek.html>. Data dostępu. 14 stycznia 2020.

WielkieSlowa.pl (2020). William Golding - cytaty. Online: <https://www. wielkieslowa.pl/26553-mysle-ze-to-glupie-ze-strony-kobiet-by-udowadniac.html>. Data dostępu: 3 listopada 2020.

Yngve, V. H. (1975). Human Linguistics and Face-to-Face Interaction. W: A. Kendon, R. M. Harris, M. R. Key (red.), Organization of Behavior in Face-to-Face Interaction (s. 47-62). The Hague - Paris: Mouton Publishers. 
dr hab. Arkadiusz Jabłoński - prof. UAM, Zakład Japonistyki, Instytut Orientalistyki, Wydział Neofilologii Uniwersytetu im. Adama Mickiewicza w Poznaniu.

\section{Nowa deiksa? Nowa anafora? Nowa semantyka? Językowa gra w oczywistość płci}

Abstrakt: Badanie języka i procesów językowych wspierane jest przekonaniem o ich powiązaniu z pewną weryfikowalną rzeczywistością. Jednocześnie nie wszystkie parametry języka odzwierciedlają rzeczywistość w sposób dokładny. Co więcej, postulowanie sztywnego odzwierciedlania rzeczywistych właściwości desygnatów w języku może wykazywać znamiona manipulacyjnej gry komunikacyjnej. W artykule proponuje się analizę w terminach tak rozumianej gry kilku fragmentarycznych, acz raczej ogólnie reprezentatywnych przykładów użycia wybranych elementów o charakterze deiktycznym i anaforycznym przy zaznaczaniu płci desygnatu (nie zawsze tożsamej z rodzajem gramatycznym) w tekstach z zasobu komunikacyjnego współczesnej polszczyzny.

Słowa kluczowe: "feminatywy”, relacje niedbałe, anafora, rodzaj gramatyczny 
